\title{
TRADE REGULATION: SECTION 5 (b) OF THE CLAYTON ACT GIVEN AN INDEPENDENT ROLE
}

\begin{abstract}
Section 5(b) of the Clayton Act, which provides for suspension of the applicable statute of limitations during the pendency of Government antitrust litigation, has traditionally been limited to those cases where a Government-obtained judgment was potentially available as prima facie evidence in a subsequent private action pursuant to section 5(a) of the Clayton Act. Relying upon two recent Supreme Court decisions which viewed the private remedy broadly, the District Court for the District of Minnesota has emphasized the independent policy objectives of section 5(b) and has decreed a broader operative scope for the section.
\end{abstract}

$\mathbf{P}$ Puvate treble damage actions ${ }^{1}$ were originally designed as an important means to enforce the federal antitrust laws. ${ }^{2}$ Section 5 (b) of the Clayton Act implements this policy by suspending the statute of limitations applicable to private causes of action ${ }^{3}$ during the pendency of Government litigation, ${ }^{4}$ while section 5 (a) allows a favorable

\footnotetext{
${ }^{1}$ Section 4 of the Clayton Act allows "any person ... . injured in his business or "property" by reason of anything forbidden in the antitrust laws" to sue for treble damages, the cost of the suit, and reasonable attorney's fees. 38 Stat. 731 (1914), 15 U.S.C. $\$ 15$ (1964). States and incorporated cities, several of which were parties plaintiff in the instant proceedings, are "persons" within the meaning of $\$ 4$. Georgia v. Evans, 316 U.S. 159 (1942); Chattanooga Foundry Works v. Atlanta, 203 U.S. 390 (1906).

2 E.g., Karseal Corp. v. Richfield Oil Corp., 221 F.2d 358, 365 (9th Cir. 1955); Maltz v. Sax, 134 F.2d 2, 4 (7th Cir.), cert. denied, 319 U.S. 772 (1943); Quemos Theatre Co. v. Warner Bros., 35 F. Supp. 949, 950 (D.N.J. 1940). See generally Bicks, The Department of Justice and Private Treble Damage Actions, 4 ANTitrust BuLL. 5 (1959); Loevinger, Private Action-The Strongest Pillar of Antitrust, 3 ANTITRUsT BuLL. 167 (1958); MacIntyre, The Role of the Private Litigant in Antitrust Enforcement, 7 ANTITRUST BULI. 113 (1962).

${ }^{8}$ Private actions under $\$ \S 4$ and $4 \mathrm{~A}$ of the Clayton Act are barred "unless commenced within four years after the cause of action accrued." Clayton Act $\$ 4 \mathrm{~B}$, addcd by 69 Stat. 283 (1955), 15 U.S.C. $\$ 15$ (b) (1964).

Prior to the enactment of this section in 1955, state statutes of limitations governed private treble damage suits. See 6 Toulmin, ANTITRUst Laws of the UNITEd States $\$ \S 16.29$-:32 (1951); Comment, 61 Yare L.J. 1010, 1030 n.134 (1952).

" "Whenever any civil or criminal proceeding is instituted by the United States to prevent, restrain, or punish violations of any of the antitrust laws, but not including an action under section $15 \mathrm{a}$ of this title, the running of the statute of limitations in respect to every private right of action arising under said laws and based in whole or in part on any matter complained of in said proceeding shall be suspended during the pendency thereof and for one year thereafter: Provided, however, That whenever the running of the statute of limitations in respect of a cause of action arising under section 15 of this title is suspended hereunder, any action to enforce such cause of action shall be forever barred unless commenced either within the period of suspension or within four years after the cause of action accrued." Clayton Act $\$ 5$ (b), added by 69 Stat. 283 (1955), 15 U.S.C. $\$ 16$ (b) (1964).
} 
judgment obtained by the Government to be used as prima facie evidence against the same defendants in a private suit. ${ }^{5}$ Until recently, however, because section 5 had been narrowly interpreted, ${ }^{6}$ private actions had been of limited value in antitrust enforcement. ${ }^{7}$ In 1965 the Supreme Court re-examined the policies behind section 5 and mandated a more liberal interpretation of that section. ${ }^{8}$ The implications of this liberalization were made clear in Michigan $v$. Morton Salt Co., ${ }^{9}$ where the federal district court for the District of Minnesota considered a number of tolling problems arising under the statute of limitations provision of section $5(\mathrm{~b})$. By interpreting that section broadly, the court rendered a construction of the statute which should encourage the use of the private remedy.

Morton Salt was a consolidated private treble damage action which followed earlier criminal and civil proceedings instituted by the Justice Department against several corporations in the salt industry. The Government had obtained an indictment against the Morton, Diamond Crystal, Carey, and International Salt Companies ${ }^{10}$ on June 28,1961 , for conspiring to fix the price of rock salt sold to various state and local governments. Two weeks later, the Government instituted a civil suit against the same defendants, which was stayed pending the outcome of the criminal action. Upon conclusion

5 "A final judgment or decree heretofore or hereafter rendered in any civil or criminal proceeding brought by or on behalf of the United States under the antitrust laws to the effect that a defendant has violated said laws shall be prima facie evidence against such defendant in any action or proceeding brought by any other party against such defendant under said laws or by the United States under section 15a of this title, as to all matters respecting which said judgment or decree would be an estoppel as between the parties thereto: Provided, That this section shall not apply to consent judgments or decrees entered before any testimony has been taken or to judgments or decrees entered in actions under section 15a of this title." Clayton Act $\S 5(a)$, added by 69 Stat. 283 (1955), 15 U.S.C. $\$ 16$ (a) (1964).

- See notes 37-39 infra and accompanying text.

${ }^{7}$ Statistically, the limited value of private enforcement was rather clear. For example, between 1890 and 1940, only 175 private actions were reported and the private plaintiff was successful in only thirteen. Comment, 18 U. CHI. L. REv. 130, 138 (1950). Despite the large increase in private suits since World War 11, the private litigant's chances of success have remained dim. In the period from 1952 to 1958, private plaintiffs were successful in 20 treble damage actions but lost in 124 such actions, a six to one ratio in favor of the defendants. MacIntyre, supra note 2, at 113. See generally Guilfoil, Private Enforcement of U.S. Antitrust Laws, 10 ANTITRUST BuLL. 747 (1965).

${ }^{8}$ See Leh v. General Petroleum Corp., 382 U.S. 54 (1965); Minnesota Mining \& Mfg. Co. v. New Jersey Wood Finishing Co., 381 U.S. 311 (1965); notes 49.51 infra and accompanying text.

259 F. Supp. 35 (D. Minn. 1966).

${ }^{10}$ Besides the named defendants, American, Barton, Hardy, Cargill, and CutlerMagner were implicated as co-conspirators in the criminal action. Id. at $53 \mathrm{n} .16$. 
'of the criminal proceeding ${ }^{11}$ the civil suit was resumed, and judgment was entered against Morton and Diamond Crystal on November 24, 1964. Prior to judgment, Carey had entered into a consent decree on March 26, 1962, and International had followed suit on November 4, 1963. The judgment against Morton and Diamond Crystal was affirmed by the Supreme Court on October 26, 1965..$^{12}$ Shortly thereafter, the present private action was instituted against those companies named as defendants in the Government actions, those companies implicated as co-conspirators in the Government proceedings, and Cargo Carriers Company, which had been neither a party nor a named co-conspirator in the prior suits. ${ }^{13}$

The plaintiffs in Morton, in order to meet the requirement of section 5 (b) that their action be brought within one year after the Government suit ceased to pend, ${ }^{14}$ argued that the statute of limitations would not expire until October 25, 1966, one year after the termination of the Government's civil suit. ${ }^{15}$ Defendants Morton and Diamond asserted the relevant date to be June 7,1963 , one year after the entry of the criminal verdict. ${ }^{16}$ The court accepted the plaintiffs' contention that the duration of the criminal and civil suits should be joined or "tacked" together for purposes of suspending the statute of limitations. ${ }^{17}$ Moreover, the court determined that the 1966 date also marked the end of the limitation period for defendants Carey and International, notwithstanding the entry of their consent decrees in 1962 and $1963 . .^{18}$ Finally, the court held the 1966 date controlling even as to private defendants who had not been named defendants in either of the prior Government proceedings, since "substantial indentity" between the causes of action in the Government and private suits could be demonstrated. ${ }^{19}$

${ }^{21}$ All defendants, except Carey, which had entered a plea of nolo contendere, were found not guilty on June 7,1962 . Id. at 45.

12 Morton Salt Co. v. United States, 382 U.S. 44 (1965).

13259 F. Supp. at 42.

14 See note 4 supra.

${ }_{15}$ See note 12 supra and accompanying text.

10 See note 11 supra.

17259 F. Supp. at 51 .

${ }^{18}$ In response to the defendants' contention that a defendant-by-defendant analysis was required to determine when the statute of limitations had run, plaintiffs urged that the Government proceedings must be considered as a unit so that the action did not cease to pend with respect to one defendant until the termination of the suits against all defendants. Id. at 46 . The Morton court accepted the latter point of view. Id. at 48.50 .

${ }^{10} \mathrm{Id}$. at 55. The Justice Department initiated its investigation into the salt in. 
Statutes of limitations are designed to force prospective plaintiffs to assert their claims in a timely fashion. ${ }^{20}$ Their stringency is often mitigated, however, by exceptions which toll the running of the stated limitation period. ${ }^{21}$ In turn the various tolling provisions have uniformly been strictly construed to prevent undue prolongation of the limiting periods. ${ }^{22}$ Thus, a plaintiff can avail himself only of those exceptions applicable to him when his cause of action accrued; any exception arising subsequently will not operate to toll the statute. ${ }^{23}$ Further, the period of such an exception may not be added to or "tacked" to that of an exception already applicable to a plaintiff when his cause of action accrued. ${ }^{24}$ On the other hand, the

dustry in 1959. In May 1959, a grand jury was empaneled in Springfield, Illinois, but was later discharged without taking any formal action. Another grand jury was convened in Springfield in February 1960 , but again no indictments were returned. A third attempt was made in St. Paul, Minnesota, where a grand jury was convened in September 1960 and subsequently returned several indictments on June 28, 1961. Id. at 43 .

A fourth issue in the Morton case involved the plaintiffs' allegation that the Government criminal action was instituted and the statute of limitations tolled by the convening of the first grand jury in May 1959. The point is relevant in order to determine the first year for which the plaintiffs may seek damages, since, in a private suit for damages, a plaintiff may recover only such damages as were sustained within the applicable period of limitations immediately preceding the bringing of the action or the tolling of the statute by a Government suit. 6 Toulmin, op. cit. supra note 3, \$27.11. Hence, in the instant case, the earlier the statute was tolled by the Government action, the farther back in time the plaintiffs could go in asserting their damage claims. In its sole rebuff of the plaintiffs' position, the court in Morton held that the Government action was instituted for tolling purposes with the return of the indictment and not with the convening of the initial grand jury. $259 \mathrm{~F}$. Supp. at 45 . See note 65 infra.

${ }^{20}$ Specifically, statutes of limitations serve to prevent surprises through the revival of claims after evidence has been lost, memories have faded, and witnesses have disappeared. E.g., Burnett v. New York Cent. R.R., 380 U.S. 424, 428 (1964); Chase Sec. Corp. v. Donaldson, 325 U.S. 304, 314 (1944); Developments in the Law: Statutes of Limitations, 63 Harv. L. Rev. 1177, 1185 (1950); Note, 33 So. CaL. L. Rev. 321, 324 (1960); Note, 9 W. REs. L. REv. 86, 89-90 (1957).

Also, statutes of limitations limit the ability of plaintiffs to procrastinate in instituting suit so as to allow damages to build up. This consideration is very important in the antitrust field where treble damages are possible.

${ }_{21}$ Typical disabilities for which a statute is tolled include infancy, mental incapacity, imprisonment, absence from state, concealment, duress, and death. See Blume \& George, Limitations and the Federal Courts, 49 Micr. L. REv. 937, 974-78 (1951); Note, 9 W. REs. L. REv. 86, 96 (1957).

${ }^{22}$ The courts have held, as a rule of construction, that any exception to the statute of limitations must be expressly spelled out in the statute itself. Vance v. Vance, 108 U.S. 514, 521 (1883); Gershinsky v. State, 6 App. Div. 2d 964, 966, 176 N.Y.S.2d 667, 670 (1958).

${ }^{23}$ E.g., DeArnaud v. United States, 151 U.S. 483, 496 (1894); McDonald v. Hovey, 110 U.S. 619, 630 (1884); Strungosky v. Beatrice Marsh Holding Co., 196 Misc. 162, 164, 93 N.Y.S.2d 595, 596 (Sup. Ct. 1949).

2t Rose v. Petaluma \& S.R. Ry., 64 Cal. App. 213, 217, 221 Pac. 406, 408 (Dist. Ct. App. 1923); see cases cited in Annot., 53 A.L.R. 1303, 1306-13 (1928). 
statute of limitations will be suspended during the longer of two or more tolling periods which were simultaneously applicable to a plaintiff when his cause of action arose. ${ }^{25}$

The enactment of a four-year federal statute of limitations in 1955 applicable to private treble damage' suits ${ }^{26}$ clearly indicates that Congress was aware of the difficulties which confronted defendants who, under the prior law, ${ }^{27}$ had been forced to weather diverse, and often lengthy, state limitation periods. ${ }^{28}$ However, both before and since the 1955 legislation, "tacking" problems have received only scant judicial consideration. ${ }^{29}$ The authority which does exist in relation to section $5(\mathrm{~b})$ indicates that the general rules relating to the statute of limitations will be applicable. ${ }^{30}$ For example, in Dickinson, Inc. v. Kansas City Star Co., ${ }^{31}$ the plaintiff had brought suit within one year of the termination of the prior Government civil suit but not within one year of the termination of the prior criminal action. Both proceedings had been instituted simultaneously. The defendant admitted that section 5 (b) did not bar plaintiff's cause of action $^{32}$ but argued that the prior criminal judgment could not be used as prima facie evidence since section $5(\mathrm{~b})$, read as correlative with section $5(\mathrm{a})$, meant to preclude prima facie use of a prior judgment in an action brought more than one year after that judgment was rendered..$^{33}$ The Dickinson court invoked the gen-

${ }^{25}$ E.g., Thorp v. Raymond, 57 U.S. (16 How.) 247, 250 (1853); Strungosky v. Beatrice Marsh Holding Co., 196 Misc. 162, 93 N.Y.S.2d 595 (Sup. Ct. 1949); Powell v. Koehler, 52 Ohio St. 103, 39 N.E. 195 (1894). See cases cited in Annot., 53 A.L.R. 1303, 1304.06 (1928).

20 See note 3 supra.

27 See ibid.

${ }^{28}$ See 259 F. Supp. at $52 \&$ n.15.

20 Because "tacking" questions can arise only when there are two or more exceptions which toll the relevant statute of limitations, the fact that the Government often does not institute both civil and criminal proceedings against the same defendants diminishes tbe problem. Cf. 6 Toulmin, op. cit. supra note 3, \$1.3; Bergson, Current Antitrust Policies, 38 ILL. B.J. 170 (1949). Moreover, when either simultaneous or successive suits are brought and the Government is successful in neither, there is little incentive for private plaintiffs to attempt recovery. Cf. Comment, 61 YALE L.J. 1010, 1060.61 (1952). Alternatively, if the Government is successful in its initial suit, private plaintiffs have little reason to await the outcome of the second action. This is especially true since the defendants usually negotiate consent decrees or enter pleas of nolo contendere in the second action, whichever is appropriate. See note 69 infra.

${ }^{80}$ See notes 2l-25 supra and accompanying text.

${ }^{31} 173$ F. Supp. 423 (W.D. Mo. 1959).

${ }^{22} I d$. at 425 .

${ }^{\text {ss }}$ See $i d$. at 424 . 
eral rule of concurrent exceptions to a statute of limitations ${ }^{34}$ and reasoned that since the plaintiff was entitled, in any event, to wait until one year after the termination of the longer period of suspension, it should not be denied the prima facie benefits of section 5 (a) until that one year had expired. ${ }^{35}$ The court indicated, in dictum, that if the Government had instituted its civil action after commencement of the criminal proceeding, extension of the tolling of the limitation period to one year beyond the termination of the civil action would have involved impermissible "tacking." 36

Perhaps the most significant facet of the Dickinson case was the defendant's assertion that sections 5 (a) and 5 (b) are correlative. The federal courts, having developed an early animosity toward the treble damage aspect of private suits, ${ }^{37}$ narrowly interpreted section 5 (a) as a collateral estoppel statute. ${ }^{38}$ Pursuant to this

\footnotetext{
${ }^{84}$ See note 25 supra and accompanying text.

${ }^{85} 173$ F. Supp. at 424-25. The court did note that the general rules of limitation of actions were not entirely apposite in $\S 5$ (b) situations. Since the federal statute of limitations may be tolled after the accrual of a private cause of action, the rule that a plaintiff may not take advantage of an exception which applies to him after the accrual of his cause of action (see note 23 supra and accompanying text) is not applicable. Nevertheless, the court was able to analogize the private plaintiff's privilege to have the statute tolled during the pendency of Government suits to the general rules regarding concurrent and successive exceptions to statutes of limitations. $173 \mathrm{~F}$. Supp. at 424-25.

so Id. at 425.

${ }^{87}$ See Paramount Film Distrib. Corp. v. Applebaum, 217 F.2d 101, 105 (5th Cir. 1954); Allgair v. Glenmore Distilleries, 91 F. Supp. 93, 97 (S.D.N.X. 1950); Westor Theatres, Inc. v. Warner Bros. Pictures, Inc., 41 F. Supp. 757, 762 (D.N.J. 1941); Loevinger, supra note 2, at 170; McConnell, The Treble Damage Action, 1950 U. ILL. L.F. 6596,665 .

${ }^{88}$ Emich Motors Corp. v. General Motors Corp., 340 U.S. 558, 568.69 (1951); Steiner v. 20th Century Fox Film Corp., 232 F.2d 190, 196 (9th Cir. 1956); Firth \& Walnut, Inc. v. Loew's, Inc., 176 F.2d 587, 593 (2d Cir.), cert. denied, 338 U.S. 894 (1949); see Timberlake, The Use of Government Judgments or Decrees in Subsequent Treble Damage Actions Under the Antitrust Laws, 36 N.Y.U.L. Rev. 991 (1961).

As interpreted, a Government judgment or decree is prima facie evidence only as to matters actually determined in the Government suit. Hence tbe private plaintiff must show strict identity between his suit and the Government suit in order to use any prior judgment. He must demonstrate the following:

(l) that his complaint relates to events which occurred at the same time as those which led to the Government's judgment, Orbo Theatre Corp. v. Loew's, Inc., 156 F. Supp. 770, 777 (D.D.C. 1957), aff'd, 261 F.2d 380 (D.C. Cir. 1958), cert. denied, 359 U.S. 943 (1959);

(2) that the events complained of took place in the same locality as those specified in the prior judgment, Theatre Enterprises, Inc. v. Paramount Film Distrib. Corp., 346 U.S. 537, 543 (1954); Robbinsdale Amusement Corp. v. Warner Bros. Picture Distrib. Corp., 141 F. Supp. 134, 143 (D. Minn. 1955), appeal dismissed, 235 F.2d 782 (8th Cir. 1956);
}

(3) and that his claim is based upon the same type of events as was the Government 
narrow approach, section 5 (b) was treated merely as the complement of section 5 (a), with the result that the restrictive rules of collateral estoppel were carried over to the former section. ${ }^{30}$ Thus, the statute of limitations was held, to be tolled only as to those defendants against whom the private plaintiff would be able to use a prior Government judgment as prima facie evidence or would have been able to use such a judgment had the Government action been successful.40

The case most clearly adopting this restrictive approach is Sun Theatre Corp. v. RKO Radio Pictures, Inc. ${ }^{41}$ There the Seventh Circuit Court of Appeals held that a defendant-by-defendant analysis must be adopted in order to determine when a Government action against multiple defendants ceased to pend. The court asserted that there would be no purpose in interpreting "pendency." to continue as to a particular defendant beyond the point where a final judgment was rendered or a consent decree entered into by that defendant. ${ }^{42}$ Rather, the court believed such a practice would only result in stale litigation and excessive hardship to the defendants. ${ }^{43}$

case, Eagle Lion Studios v. Loew's, Inc., 248 F.2d 438, 444-45 (2d Cir. 1957), aff'd, 358 U.S. 100 (1958).

For criticism of the collateral estoppel approach, see Hardy, The Evisceration of Section 5 of the Clayton Act, 49 GEO. L.J. 44 (1960); Comment, 39 N.Y.U.L. REv. 518, 521-22 (1964).

Interestingly, the Morton court adopted the traditional narrow interpretation of $\$ 5$ (a) outlined above. See $259 \mathrm{~F}$. Supp. at 59-75.

so Because the courts determined that the sole purpose of $\S 5$ (b) was to operate in conjunction with the exercise of $\S 5$ (a), it was inevitable that the scope of operation of the two sections would be held to be identical. Fence, just as a Government decree could not be used against a private defendant unless the allegations of the private plaintiff paralleled the findings of the court in the Government action, so the statute of limitations could not be tolled as to a private defendant unless the same identity could be shown between the matters complained of by the Government in the prior suit and the private cause of action. The principle was clearly expressed in Steiner $\mathbf{v}$. 20th Century Fox Film Corp., supra note 38, where the court stated: "General allegations of conduct in violation of the antitrust laws unrelated to the same conduct alleged in a public suit are insufficient to toll the running of a statute of limitations. A greater similarity is needed than that the same conspiracies are alleged. The same means must be used to achieve the same objectives of the same conspiracies by the same defendants ... . The general rules of collateral estoppel apply." 232 F.2d at 196. Accord, Samuel Goldwyn Prods., Inc. v. Fox West Coast Theatres Corp., 146 F. Supp. 905, 907 (N.D. Cal. 1956); Momand v. Universal Film Exchange, 43 F. Supp. 996, 1012 (D. Mass. 1942), aff'd, 172 F.2d 37 (Ist Cir. 1948), cert. dcnicd, 336 U.S. 967 (1949). to E.g., Sun Theatre Corp. v. RKO Radio Pictures, Inc., 213 F.2d 284, 290.92 (7th Cir. 1954); Farmington Dowel Products Co. v. Forster Mfg. Co., 223 F. Supp. 967, 971 (D. Me. 1963).

11 213 F.2d 284 (7th Cir. 1954).

12 Id. at 292.

${ }^{4}$ Ibid. 
Moreover, the Sun Theatre court held that, since a decree obtained by the Government could only be used as prima facie evidence in a private suit against those defendants who had also been Government defendants, section 5 (b) could not operate to toll the statute of limitations as to a private defendant who had not been a named defendant in the Government action. ${ }^{44}$ The court's clearly articulated premise was that the tolling benefits accorded under section 5 (b) were available only when the plaintiff was potentially in a position to invoke section 5 (a). ${ }^{45}$

The Morton court repudiated the philosophy of Sun Theatre and similar cases, ${ }^{46}$ relying heavily upon the rationale of the Supreme Court's decisions in Minnesota Mining \& Mfg. Co. v. New Jersey Wood Finishing Co. ${ }^{47}$ and Leh v. General Petroleum Corp. ${ }^{48}$ These latter cases had asserted that sections $5(a)$ and $5(b)$ were not entirely co-extensive and that the additional policy served by section 5 (b) was to make available to the private plaintiffs all benefits which might flow from the prior Government action, in addition to a final judgment or decree to be used under section 5 (a). ${ }^{49}$ Special em-

"Id. at 291. Sun Theatre and other cases focused upon the supposed interdependence of $\S \S 5$ (a) and $5(\mathrm{~b})$ and also upon the particular wording of $\S 5$ (b). Specifically, these cases construed the phrase "matters complained of" in $\S 5$ (b) as referring to overt acts of named defendants which had been detailed by the Government in its prior action. Since the private plaintiff's action must be based in whole or in part upon such "matters complained of," the proposition was deduced that $\$ 5$ (b) could operate to suspend the statute of limitations only as to such named Government defendants. See Steiner v. 20th Century Fox Film Corp., 232 F.2d 190, 196 (9th Cir. 1956); Charles Rubenstein, Inc. v. Columbia Pictures Corp., 154 F. Supp. 216, 218 (D. Minn. 1957), aff'd, 289 F.2d 418 (8th Cir. 1961); Christensen v. Paramount Pictures, Inc, 95 F. Supp. 446, 455 (D. Utall 1951).

15 The court in Sun explicitly stated that "no public policy considerations require that the tolling provisions be more extensive than the evidentiary provisions which they are designed to protect." 213 F.2d at 292.

10 E.g., Columbia Pictures Corp. v. Charles Rubenstein, Inc., 289 F.2d 418 (8th Cir. 1961); Court Degraw Theatre, Inc. v. Loew's, Inc., 172 F. Supp. 198 (E.D.N.Y. 1959); Christensen v. Paramount Pictures, Inc., 95 F. Supp. 446 (D. Utah 1951).

4781 U.S. 311 (1965).

4382 U.S. 54 (1965).

10381 U.S. at 317. Minnesota Mining concerned the applicability of $\S 5(\mathrm{~b})$ to Federal Trade Commission actions. The Court held that proceedings before the FTC served to toll the statute of limitations regardless of whetber $\$ 5$ (a) was also applicable. The Court based its conclusion partially upon certain textual distinctions between $\$ \$ 5$ (a) and $5(b)$. See $i d$. at 316-17. More importantly, the Court perceived differing policies behind the two provisions. The relatively narrow scope of $\$ 5$ (a) permits private plaintiffs to take advantage of prior Government judgments or decrees by providing such plaintiffs with "as large an advantage as the estoppel doctrine would afford had the Government brought suit." Id. at 317 (quoting Emich Motors Corp. v. General Motors Corp., 340 U.S. 558, 568 (1951)). On the other hand, the broad purpose of 
phasis was placed upon the evidentiary benefits which would accrue to private plaintiffs if the pleadings, transcripts, documents, and exhibits from prior Government actions were made available. ${ }^{50}$ As a result, these cases specifically rejected the collateral estoppel approach to section 5 (b) and extended its scope beyond that of section 5 (a), an approach believed to be consistent with the congressional purposes behind section 5 (b). ${ }^{51}$

Morton accorded the district court an opportunity to apply the philosophy of Minnesota Mining and Leh to a wide range of tolling problems. Emphasizing the strong policy foundation of section 5 (b) to accord private plaintiffs all the evidentiary benefits of prior Government actions, ${ }^{52}$ the court was able to dismiss the defendants'

$\$ 5(\mathrm{~b})$ is to assist private plaintiffs "in utilizing any benefits they might cull from government antitrust actions." 381 U.S. at 317. (Emphasis added.)

In $L e h$, the Court rejected the proposition that the private litigant's complaint must be virtually identical with that of the Government in the prior suit in order to suspend the statute of limitations. Thus, the plaintiff need not allege the same means, objectives, and conspiracy as presented in the Government complaint in order to take advantage of $\S 5$ (b). Rather, there need only be a "substantial identity" between the allegations of the private plaintiff and the Government as to the type of conspiracy, geographic area involved, time period, and defendants. See 382 U.S. at 63-65; Union Carbide \& Carbon Corp. v. Nisley, 300 F.2d 561, 559-70 (10th Cir. 1961). See generally Note, 41 Notre Dame Law. 811 (1966).

${ }^{80} 381$ U.S. at $317 ; 382$ U.S. at 58-59. See Loevinger, Handling a Plaintiff's Antitrust Damage Suit, 4 ANTITRUst Burc. 29, 44 (1959).

52 The legislative history of $\S 5(\mathrm{~b})$ is inconclusive. It does appear, however, that Congress was concerned about the plight of the private plaintiff and intended to aid him in prosecuting his claims. See Emich Motors Corp. v. General Motors Corp., 340 U.S. 558, 568 (1951); Guilfoil, supra note 7, at 765.66; Comment, 1963 Wis. L. REv. $459,461-62$. When $\$ 5$ was amended in 1955 , the substantial evidentiary benefit of a complete Government suit, aside from prima facie benefits of a judgment, was ap. parently recognized and deemed to be an important function of $\$ 5(\mathrm{~b})$. See S. REP. No. 619, 84th Cong., lst Sess. (1955); Minnesota Mining \& Mfg. Co. v. New Jersey Wood . Finishing Co., 332 F.2d 346, 359 (3d Cir. 1964), aff'd, 381 U.S. 311 (1965); Note, 41 Notre DaMe LAw. 811,817 n.48 (1966).

While aware of the great evidentiary benefit of a complete Government suit, Congress seemingly did not consider the application of $\S 5$ (b) to any particular tolling problems. The records do not disclose any specific authorization for expanding the scope of $\S 5$ (b) beyond that of $\S 5$ (a). Lacking any clear directive from Congress, the Morton court sought to interpret $\S 5$ (b) so as to implement the policies behind the section. Inconclusive legislative history notwithstanding, the courts had determined that \$5.(b) was meant to secure all the benefits of prior Government actions to private plaintiffs (see note 46 supra and accompanying text) and to allow private enforcement to assume an important role in overall antitrust enforcement. See note 2 supra and accompanying text.

Several prominent writers have taken the position that private action is a more desirable means of enforcing the antitrust laws than government action, though not a substitute for it. See Bicks, supra note 2, at 8; Loevinger, Handling a Plaintifj's Antitrust Damage Suit, 4 AntrrRusr BuLc. 29, 52 (1959); Loevinger, Private Action-The Strongest Pillar of Antitrust, 3 ANTITRUst Buxc. 167 (1958); see note 84 infra.

82259 F. Supp. at 52. 
argument that "tacking" in the instant case tended to frustrate the clear policy behind the statute of limitations. ${ }^{53}$ The court admitted that there may be some situations in which "tacking" successive Government actions together would "result in treble damage claims of such vintage that it would be patently unreasonable to assume that Congress meant to allow 'tacking' under $\$ 5(\mathrm{~b})$. "54 Nevertheless, because only a two-week period separated the filing of the successive Government actions involved in Morton, the court concluded that a balancing of possible evidentiary benefits arising from the Government's second action against the actual hardships encountered by the defendants dictated that "tacking" should be allowed."

Furthermore, the court held that the Government civil action continued to pend as to each defendant until concluded as to all defendants since the private plaintiff could make an intelligent evaluation of his case only when all of the evidentiary benefits of prior Government actions were available to him. The court reasoned that a particular defendant was likely to be implicated by his co-conspirators in testimony subsequent to the point at which he capitulated.56 Admitting that its ruling might allow a defendant who had negotiated a civil consent decree to be sued a number of years after he ceased to have any connection with the Government litigation, ${ }^{57}$ the court nevertheless believed that to hold for the defendants would result in hardship equally as great to the private plaintiff as well as frustrate the purposes behind section $5(\mathrm{~b}) .{ }^{58}$

The Morton court went a step further and accepted the plaintiffs' argument that section 5 (b) may toll the statute of limitations against private defendants who were not named defendants in the prior Government action. ${ }^{59}$ Here again the court emphasized that its approach gives the private plaintiff the benefit of all Government evidence before he is forced to institute suit. ${ }^{60}$ The statute itself contains no explicit reference to particular defendants. On the

\footnotetext{
83 Ibid.

Id. at 51. (Emphasis added.)

ED The fact that no evidentiary benefits accrued in fact from the second Government suit was deemed irrelevant by the court, as such a determination could be made only with the aid of hindsight. The court apparently believed that private litigants should not be required to read the future at their own peril. Id. at $\mathbf{5 2}$.

sB Id. at 48 .

57 Id. at 49.

${ }^{68} I d$. at 50; cf. note 79 infra.

so 259 F. Supp. at 56.

os Ibid.
} 
other hand, it clearly states that the private cause of action must be based in whole or in part on matters complained of by the Government. ${ }^{61}$ Conceivably, the Morton court believed, the private plaintiff's claim against a particular non-Government defendant may be substantially the same as the prior Government cause of action against the designated defendants, and, therefore, the "in part" requirement of section 5 (b) could be met. ${ }^{62}$ Indeed, the new defendant is made a party to the private suit precisely because he allegedly participated, to some extent, in the acts of which the Government complained in the prior action. ${ }^{63}$ The court rejected the non-Government defendants' contentions that such an interpretation of section $5(\mathrm{~b})$ penalized them for the actions of parties over whom they had no control because the non-Government defendants could not prevent prolongation of the actions by the named defendants. Acknowledging the truth of the argument, the court noted that, since the defendants were not deprived of their day in court, no protected rights were prejudiced by its holding. ${ }^{.4}$ The

\footnotetext{
ax See note 4 supra.

02259 F. Supp. at 55 n.18. The court noted that the Leh case, while specifically concerned only with the application of $\S 5$ (b) to defendants who had also been named defendants in the prior Government action, had held that there need only be a "substantial identity" between the private cause of action and the prior Government action in order to toll the statute of limitations. 1d. at 54; see note 49 supra. The Supreme Court had suggested that considerations of strategy often dictate which parties are named as defendants in the Government suit. Furthex, it was indicated that the private plaintiff in his later action may properly name as defendants parties against which the Government lad not initially proceeded because of their relative insignificance. 382 U.S. at 63-64. Thus, the Morton court inferred that the mere fortuity that a particular private defendant was not a named defendant in the prior Govern. ment action will not conclusively determine whether the private plaintiff has met the "substantial identity" test as to that defendant if other substantial connections can be shown. 259 F. Supp. at 55.

Such a conclusion would be consistent with the Supreme Court's explicit statement in Leh that to construe $\$ 5$ (b) narrowly "would be to resurrect the collateral estoppel approach declared in Steiner and rejected by the Court in Minnesota Mining." 382 U.S. at 65 . The proposition that the statute of limitations cannot be tolled as to a private defendant who was not also a named defendant in the prior Government suit is a direct result of the collateral estoppel approach. See notes 38-39 supra. Hence, the loolding of the court in Morton on the non-Government defendant issue follows logically from Leh's rejection of the estoppel view of $\$ 5(\mathrm{~b})$.

os In a case such as Morton, in which the crux of the private plaintiff's action is that the various defendants conspired together to violate the antitrust laws, it is hardly possible for the private plaintiff to complain of the actions of a non-Government defendant except within the broader context of the actions of all defendants, some of whom were parties to the Government action. The private cause of action in such cases must almost of necessity be based partly upon matters complained of by the Government in the prior proceeding.

os 259 F. Supp. at 56.
} 
court also rejected the arguments that new defendants would be hampered by a paucity of evidence in the private suit due to a lack of notice of such possible prosecution and that normal business activities would be unreasonably impaired by the threat of treble damage claims. ${ }^{65}$ While the Supreme Court opinions in Minnesota Mining and Leh provide strong support for the foregoing conclusions, certain aspects of the Morton decision merit closer scrutiny.

By deciding, in effect, that the Government suits were for all intents and purposes filed simultaneously ${ }^{66}$ and that the plaintiffs could thus await the termination of the longer suspension period, the court purported to invoke the general rule regarding concurrently applicable exceptions to statutes of limitations. ${ }^{67}$ Such a manipulation of the rule of concurrency was seemingly justified in the instant case, for to make the availability of the benefits of Government criminal and civil actions contingent upon whether the Government institutes those suits simultaneously is to elevate mere form over substance. ${ }^{68}$

However, it seems clear that the determinative factor was not dependent upon the Government's near simultaneity in the institution of the suits. To a great extent, the procedural conduct of the Government in prosecuting criminal and civil suits against the same defendants precludes the existence of any substantial difference in

${ }^{\circ 5}$ Ibid. The court's rejection of the plaintiffs' argument that the statute of limitations was tolled by the convening of the initial grand jury in May 1959 (see note 19 supra) is not a retreat from the policy to make available to private plaintiffs all benefits which might flow from the prior Government actions. As the court noted, $259 \mathrm{~F}$. Supp. at 45 , private litigants could rarely derive any evidentiary benefits from grand jury proceedings because of their traditional secrecy.

Discovery of grand jury records is limited to those cases where there are "extreme circumstances clearly indicating compelling necessity in the interests of justice." In re Grand Jury Proceedings, 29 F.R.D. 151, 155 (E.D. Pa. 1961), aff'd, 309 F.2d 440 (3d Cir. 1962). The fact that such discovery might result in substantial savings of time and money in a particular case is insufficient to meet this test. In re Grand Jury Proceedings, supra; Appeal of the State of California, 195 F. Supp. 37, 41 (E.D. Pa. 1961). Hence, $a$ holding that the statute of limitations is tolled by the empaneling of a grand jury would be of little value in providing new sources of evidence. The court in Morton also emphasized that 5 (b) tolls the statute of limitations only where the Government brings an action "to prevent, restrain, or punish violations of any of the antitrust laws...." The Morton court believed a grand jury to be an investigative body whose function did not involve punishment, restraint, or prevention. 259 F. Supp. at 44.

${ }^{\circ 0}$ See note 55 supra and accompanying text.

or See note 25 supra and accompanying text.

${ }^{68}$ In Morton, the actual period of suspension would have been no different had the Government suits been instituted simultaneously. See note 69 infra and accompanying text. 
suspension periods between suits initiated simultaneously and those initiated successively and "tacked" together. The reason is that the actual period of suspension in any case depends upon the length of time necessary to conclude the two actions. Allowing the "tacking" together of successively instituted, but concurrently pending, criminal and civil actions would result in a prolongation of the suspension period only if such actions were disposed of successively while concurrently initiated suits were disposed of concurrently. As a matter of fact, substantial policy reasons favor successive trials in any event, ${ }^{69}$ and this seems to be the general Government approach regardless of the manner in which the suits are instituted. ${ }^{70}$ Insofar as this is true, any distinction in terms of the suspension period between concurrently and successively initiated criminal and civil actions is without substance and presumably may not stand as the true decisional basis in Morton.

Viewed in this light, the Morton court must be read as positing that the resolution of "tacking" problems is primarily a matter of balancing the hardships incurred by particular defendants against the benefits accruing to private plaintiffs and to the public generally. ${ }^{71}$ The crucial question, of course, is when those hardships weigh sufficiently in the balance to produce a result contrary to that reached in Morton. As a general proposition, where "tacking" is

${ }^{\circ}$ The strong reason for first trying the criminal suit is that, if a guilty verdict is secured, the doctrine of collateral estoppel is available to the Government in a subsequent civil action as to questions of fact adversely determined against the same defendants. See Emich Motors Corp. v. General Motors Corp., 340 U.S. 558, 568.69 (1951); Local 167, Teamsters Union v. United*.States, 291 U.S. 293, 298 (1934); 6 ToulMiN, ANTIrRUST Laws of THE UNITEd States \$7.9, at 230 (1951). On the other hand, if the defendants are acquitted in the criminal action, the judgment is not res judicata in a later civil suit. E.g., United States v. National Ass'n of Real Estate Bds., 339 U.S. 485, 493.94 (1950); Helvering v. Mitchell, 303 U.S. 391, 397 (1938); Unitcd States, v. United States Gypsum Co., 51 F. Supp. 613, 614 (D.D.C. 1943).

Also, if the Government is successful in obtaining a verdict in the criminal suit, the defendants will usually negotiate consent decrees in disposition of the civil action. If, by chance, the civil action is tried first and the Government obtains a favorable judg. ment, the defendants will usually file nolo contendere pleas in the rclated criminal action. United States v. National City Lines, 334 U.S. 573, 595-96 n.45 (1948) (quoting the Brief for the Government); 6 Toulmin, op. cit. supra, $\$ 7$, at 229 . Thus, considerable time and expense can be saved if the suits are not prosecuted concurrently.

${ }^{\circ 0} \mathrm{It}$ appears that the civil and criminal suits are rarely tried concurrently even if commenced concurrently. United States v. National City Lines, supra note 69, at 595-96 n.45 (quoting the Brief for the Government). Generally, the criminal suit is tried first. See United States v. National Ass'n of Real 'Estate Bds., supra note 69, at 487; United States v. A. B. Dick Co., 7 F.R.D. 442 (N.D. Ohio 1947); note 69 supra.

${ }^{71}$ See note 85 infra and accompanying text. 
allowed, parties to one or more of the prior Government actions will not be treated unfairly since they will certainly be aware of the probability of future private actions against them. Furthermore, the very act of defending in Government litigation serves to preserve the "freshness" of the evidence, records, and witnesses which would be needed in any subsequent private suit. ${ }^{72}$

The foregoing observation loses much of its force, however, when applied to those who were not named defendants in the Government suits. For defendants in this class, even where "tacking" is not involved, there may be a lengthy period during which they will have no interest in the Government litigation. This situation gives rise to several problems. First, a company not sued by the Government might be unaware that the statute of limitations was being tolled against it. ${ }^{73}$ Such a company would be vulnerable to surprise by a future private plaintiff and would possibly find itself without the necessary evidence to defend itself effectively. Secondly, even if the non-Government party were aware of the Government litigation, he would be forced to conduct expensive investigations so as to have adequate evidence on hand in the event of future private action. This necessity would compound the already expensive burden of corporate record retention. ${ }^{74}$

Since the above problems apply to non-Government defendants in the first instance, any "tacking" which substantially prolongs the suspension period would greatly compound the difficulties of the non-Government defendant. Although the Morton case did not involve any such prolongation even though "tacking" was allowed, ${ }^{75}$ it is important to note at this point that the reasoning of the court would sustain "tacking" in situations where the institution of suc-

\footnotetext{
${ }^{72}$ See 259 F. Supp. at 53.

7s Parties named as co-conspirators in the Government actions would certainly have adequate notice of possible future private action. However, the Morton court established a conclusive presumption to the same effect with regard to private defendants who had no part in the prior Government litigation. Id. at 56. The court in Morton believed that a defendant would have sufficient familiarity with its own affairs so as to be able to ascertain whether the potential existed for future private action against it. In many cases, especially where large corporations are involved, this presumption is probably reasonable. Where a small, local concern is involved, however, or where the Government litigation concerns a related industry and the non-Government defendant is convinced of his own innocence, the presumption of awareness is less tenable.

7* BNA Antitrust \& Trade Reg. Rep., Nov. 15, 1966, p. B-1, at B-3.

${ }^{35}$ See text following note 68 supra.
} 
cessive Government suits would produce lengthy suspensions of the statute of limitations. For example, if the Government should institute criminal or civil actions piecemeal against various defendants, an extremely long suspension of the statute could result from the joining together of the multitude of separate suits. ${ }^{76}$ A private plaintiff, utilizing the policy arguments set forth in Morton, could cogently argue that "tacking" should be allowed in such a situation. ${ }^{77}$ The

${ }^{70}$ See Philco Corp. v. Radio Corp. of America, 186 F. Supp. 155 (E.D. Pa. 1960). In this case, Philco instituted a treble damage action against General Electric, R.C.A., A.T. \& T., and Western Electric. The private suit was based upon three separate Government actions involving the above companies. The Government action against General Electric was pending from 1949 until 1953, against A.T. \& T. and Western Electric from 1949 until 1956, and against R.C.A. from 1954 until 1958. Had "tacking" been allowed the suspension period would have been seventeen years. In fact, the Philco court treated each defendant separately for statute of limitations purposes. Id. at $160-61$.

It should be noted, however, that the Philco situation is clearly distinguishable from Morton. The Government litigation prior to Morton consisted of criminal and civil suits against the same defendants, whereas the Government litigation prior to Philco consisted of three successive civil actions against different defendants. Because of the procedural considerations outlined previously, see text following note 68 supra, "tacking" in Morton did not result in any prolongation of the suspension period over what would have resulted had the suits been instituted concurrently. This would not have been true in the 'Philco situation. Had the suits been initiated concurrently, a single, consolidated trial probably would have resulted. On the other hand, to have allowed the "tacking" of successive suits would have resulted in a substantial prolongation of the suspension period.

Aside from the Morton and Philco possibilities, a third situation might occur. It is important to note that the Government suits prior to Morton, while successively instituted, were nevertheless pending concurrently. According to the provisions of $\S 5$ (b), the statute of limitations is suspended for one year beyond the conclusion of a Government suit. See note 4 supra. Hence, as compared with suits concurrently pending, successive suits, even against the same defendants, might result in a prolongation of the suspension period of up to a year if the Government waited until the conclusion of its first action and later instituted a second suit within the one-year period allotted by 5 (b).

Here, however, the possible prolongation of the suspension period is slight when compared with the Philco situation. Nevertheless, the procedure outlined produces a time gap which might well lull many parties into a false sense of security. Prospective private defendants, not involved in the Government actions, might be particularly vulnerable to surprise.

The Morton court may have been aware of the problem of suits pending successively. In allowing "tacking," the court stated: "But here, the civil complaint was filed within two weeks of the indictment. Although not simultaneously commenced, the two actions were pending concurrently. ... [T]his situation falls within permissible limits ...." 259 F. Supp. at 51 . However, it is not entirely clear from the court's discussion whether the crucial factor in allowing "tacking" is the concurrent pendency of the suits or the nearness of the commencement of the actions. Furthermore, the policy arguments advanced by the Morton court in defense of "tacking" seem applicable even if the suits do not pend concurrently. See note 77 infra and accompanying text.

${ }^{77}$ The private plaintiff might argue that his cause of action against a particular defendant was based partly upon matters complained of by the Government in each 
standard of "reasonableness," alluded to by the court in Morton,78 would offer the non-Government defendant little guidance in such a case. A non-Government defendant would have to predict the length of the Government litigation and speculate whether prolonging the suspension of the statute of limitations for that amount of time would, in the eyes of a court, unduly prejudice him. If the non-Government defendant acts rationally and seeks to preserve records and apprise himself of the substance of the Government litigation, these very acts would weigh in favor of holding the statute tolled as to him. Given these considerations, a mechanical "no tacking" approach should have been adopted by the Morton court if it felt incapable of articulating any clear standards in this area. ${ }^{79}$

of the several Government actions in that his claim bears a "substantial identity" to the Government claim asserted in each such action. See notes 46,58 supra. Furthermore, he could argue that new evidence might be brought out in the later actions and that, if "tacking" is not allowed, he will be forced to institute several private suits at varying times rather than one upon the conclusion of all Government litigation.

${ }^{78}$ See 259 F. Supp. at 51.

${ }^{70}$ Obviously, one way to avoid all of the difficulties regarding non-Government defendants would be to hold that $\$ 5$ (b) does not apply to them in the first instance. Yet the reasoning of Minnesota Mining and Leh provides strong support for the Morton court's holding on this issue. See notes 49,62 supra. Furthermore, substantial hardships would accrue to the private plaintiff if $\S 5(\mathrm{~b})$ were held not to apply to nonGovernment defendants. Quite likely, the private plaintiff would be forced to institute his action against the relevant non-Government defendants before the conclusion of the Government action. While he might be able to obtain a stay of the action until the conclusion of the Government proceedings, such a decision would depend upon the discretion of the trial judge. In those cases where a stay could not be obtained, he would be faced with the prospect of litigating without the benefit of the substantial evidential aid of a prior Government action.

More importantly, there is a strong public policy reason for allowing the statute of limitations to be tolled against appropriate non-Government defendants. Such a holding will help to close a siguificant gap in overall antitrust enforcement. Previously, any company not named as a defendant by the Government was virtually immune from antitrust prosecution. While private parties could theoretically sue on their own initiative, the evidentiary and financial hardships were almost always insurmountable. See Loevinger, Private Action-The Strongest Pillar of Antitrust, 3 ANTrRust Bull. 167. 170-71 (1958). The rate of recovery was negligible. See generally Guilfoil, Private Enforcement of US. Antitrust Laws, 10 ANTITrust BuLL. 747 (1965). The holding of the Morton court on the non-Government defendant issue will provide private parties with evidence, increase their chances of success against non-Government defendants, and strengthen overall antitrust enforcement by helping to remove this undesirable loophole.

The court's decision on the tacking question also arguably aids the private plaintiff. It allows him the benefit of any new evidence brought out in the later action and also gives him the benefit of any judgment or decree rendered in that action. Yet, even if tacking were denied, the private plaintiff would still have the evidential aid of one complete Government suit at his disposal, except in those cases where a settlement was reached prior to trial. As a practical matter, however, the amount of new evidence brought out in later Government actions is not likely to be large. Furthermore, even 
As a practical matter, the court's holding that the statute remains tolled as to each Government defendant until the action is concluded as to all defendants may well have a substantial effect upon Government enforcement of the antitrust laws. The major incentive for a defendant to enter into a consent decree is that such a decree, if entered into before any testimony is taken, may not be used as prima facie evidence under section 5 (a) in a later private suit. ${ }^{80}$ Under Sun Theatre and related cases, the entry of a consent decree terminated the Government action as to that particular defendant. ${ }^{81}$ Hence, from the time the decree was entered, the private plaintiff would usually be allowed only one year-in which to bring his action against such defendant. ${ }^{82}$ Under these circumstances, the defendant obtained a double benefit. First, he escaped the operation of the prima facie provision. Secondly, he made it quite difficult for the private plaintiff, because of the one-year limit, to utilize any testimony or other evidence relating to the defendant which might have been disclosed in the subsequent Government prosecution against other alleged conspirators. However, as a result of Morton, this second benefit will no longer accrue. To the extent that considerable evidence will be introduced in the Government action implicating the defendant, such defendant may now prefer to litigate the issues rather than attempt to negotiate a consent decree. ${ }^{83}$ To some extent, a

judgments rendered in subsequent actions may be of limited value because of the collateral estoppel interpretation assigned to $\$ 5$ (a). See Minnesota Mining, 381 U.S. at 316; 61 YALE L.J. 417,425 (1952). It appears, then, that the Morton court's holding on the tacking problem confers'a less valuable privilege upon the private plaintiff when compared with the holding on the non-Government defendant issue. Further, it is the failure of the Morton court to declare any clear standards in the tacking area which threatens the non-Government defendants with the clearest possibilities of unreasonable hardship. It is in the latter area, then, that appropriate standards should be articulated so that a desirable balance may be achieved between valuable private enforcement on the one hand and fairness to private defendants on the other.

${ }^{80}$ See note 5 stipra. It should be noted that the effect of admission of a Government judgment or decree may extend beyond its use as prima facie evidence. It likely has an emotional impact upon a jury favorable to the private plaintiff. See Monticello Tobacco Co. v. American Tobacco Co., 197 F.2d 629, 633 (1952); Timberlake, supra note 38, at 991; cf. 259 F. Supp. at 61.

81 E.g., Leonia Amusement Corp. v. Loew's, Inc.; 117 F. Supp. 747, 761 (S.D.N.Y. 1953); Manny v. Wämer Bros. Pictures, Inc., 116 F. Supp. 807 (S.D. Cal. 1953); Electric Theatre Co. v. 20th Century Fox Film Corp., 113 F. Supp. 937, 944 (W.D. Mo. 1953).

82 See note 4 supra.

sa It has been argned that the failure of a consent decree to end the tolling of the statute of limitations as regards the particular consenting defendant will frustrate the Government effort to obtain such decrees. Cf. Brown, Venue and Statute of Limitations, Proceedings of the New York State Bar Association, Section on Antitrust Law 46, 56 (1952). 
substantial motivation for entering into a consent decree has been removed. However, since a Government defendant may still escape the operation of section 5 (a) by negotiating a consent decree, it is perhaps unlikely that the court's holding concerning a single termination date for tolling the statute will seriously or unreasonably hamper Government enforcement. ${ }^{84}$

The Morton case resulted in the full application of the expansive interpretation of section $5(\mathrm{~b})$ suggested by the Supreme Court in Minnesota Mining and Leh. With the collapse of the collateral estoppel approach to section $5(\mathrm{~b})$, the way was opened to alleviate considerably the burden of the private plaintiff. Undeniably, some hardships have been created for private defendants, particularly those which were not parties to the prior Government litigation. However, in balancing these interests, the court made it clear that the protection for defendants embodied in the statutes of limitations is outweighed by the interest in assisting treble damage plaintiffs to vindicate their own, as well as the public, interest. ${ }^{85}$

si The Morton holding with respect to a continuation of liability to private parties notwithstanding a consent decree may result in some slifting of antitrust enforcement from the Government to the private sector. It has been argued that private enforcement is often the more desirable because it opexates to repair the substantial economic injury often done private parties and also operates as a more effective deterrent through application of the treble damage provisions. Loevinger, Private Action-The Strongest Pillar of Antitrust, 3 ANTrrRust Bul.. 167, 168-69 (1958).

${ }^{85} 259$ F. Supp, at 53. 